\title{
COUNCIL BUSINESS
}

\author{
Proceedings of the Council, Fourth Session, I9I6-1917.*
}

The fourth session of the Council of the American Pharmaceutical Association for 19r617 was held at the Hotel Claypool, Indianapolis, on 'l'uesday, August 28, 1917, at 7.30 P.M.

Chairman I ewis C. Hopp presided.

Present: Messrs. Arny, Bibbins, Claus, Day, Dye, Eiberle, EIdred, Engelhardt, England, Fennel, Fuller, Glover, Hartmann, Hopp, Koch, Kuever, Sayre, Snow, Stewart, Turner, Utech, Whelpley and Wulling.

The minutes of the third session of the Council for I9I6-17, held at Atlantic City on September 8 , 1916, were presented and approved as published.

Motion No. 36 (Election of Members; Applications Nos. 240 to 257 inclusive), in Council Letter No. 27, was reported to have received a majority of affirmative votes.

The report of the Secretary was presented and approved. It was as follows:

Members of the Council:

GENTLEMEN :

The Council held three sessions at the Atlantic City (1916) meeting and has transacted business by mail since.

Twenty-seven Council Letters have been issued covering $5^{8}$ pages and 36 motions.

A synopsis of the motions of the Council is attached and will become a part of the records.

The members elected to date number 3 ro; the number elected last year by the first sessions of the Council at Atlantic City was 422 .

The membership of the Council numbers 40 , of which $\mathrm{I} 7$ are representatives of local branches. A number of changes of the membership have taken place. William C. Alpers and M. I. Wilbert are deceased. S. L. Hilton has been succeded by H. C. Fuller, H. P. Hynson by H. Engelhardt, George B. Kauffman by Clair A. Dye, and Thos. D. McElhenie by Jeannot Hostmann.

Charles H. Rogers resigned in December last as the representative of the West Virginia Branch, but no one has yet been chosen to succeed him.

There are 20 local branches, of which 17 at present have Council representatives; those not having are West Virginia, Montana and Cuba.

The three members of the Council elected by mail in November last for 1917-1 8 were Frederick J. Wulling, Minneapolis, Minn., George M. Beringer, Camden, N. J., and Thomas F, Main, New York, N. Y. (recently deceased).

Respectfully submitted,

J. W. ENGI,AND, Secretary of Council.

SYNOPSIS OF MOTIONS OF THE COUNCIL, I9I6-17.

Motion No. I. Election of members Nos. 1 to 8 inclusive. Carried.

Motion No. 2. That the General Secretary be authorized to furnish to the Chairman of each standing committee of the Association a reasonable supply of postage and stationery to carry on the work of the committee, to be determined by consulting the chairman. Carried.

Motion No.3. That the 1917 or Sixty-fifth Annual Meeting of the American Pharmaceutical Association be held during the week of Monday, August 27 to Saturday, September I. Carried.

Motion. No 4. That Francis E. Bibbins, of Indianapolis, be elected as I,ocal Secretary for 19r7. Carried.

Motion No. 5. Flection of members Nos. 9 to I9 inclusive. Carried.

Motion No. 6. That $\$ 2500$ be appropriated to the National Formulary IV Account with which to pay bills for the National Formulary IV. Carricd.

Motion No. 7. Election of members Nos. 20 and 21 . Carried.

* The first, second and third sessions of the Council for I9I6-Igr7 were held at Atlantic City, N. J., September 7 and 8 , r9r6. 
Motion No. 8. That, under existing circumstances, the resignation of Dr. James H. Beal as a member of the Committee on Publication be accepted with regrets. Carried.

Motion No.g. That the resignation of H. P. Hynson as a member of the Committee on Recipe Book (term expiring 1920 ) be accepted, with regrets. Carried.

Motion No. 10. Election of members Nos. 22 to 30 inclusive. Carried.

Motion No. II. That Charles H. LaWall be elected a member of the Committee on Recipe Book to succeed H. P. Hynson, term expiring in 1920. Carried.

Motion No. I2. That James $\mathrm{H}$. Beal be appointed chairman of a special committee to raise funds for a proposed $\mathrm{A}$. Ph. A. Home, and that $\mathrm{Dr}$. Beal be authorized to select his own associates on the committee and requested to report progress from time to time. Substituted by Motion No. 16.

Motion No. 13. That Elwood Hendrick, of New York City, be recommended for appointment as a member of the Tariff Commission. Carried.

Motion No. I4. That $\$ 5000$ be appropriated to the National Formulary account with which to pay bills for the National Formulary IV. Carried.

Motion No. 15. Election of members Nos. 31 to 38 inclusive. Carried.

Motion No. 16. That Dr. James H. Beal be appointed chairman of a special committee, that he is to select, to consider the project for establishing an $\mathrm{A}$. $\mathrm{Ph}$. A. headquarters; to report to the Association a comprehensive plan covering the scope of the work contemplated through such an agency; a plan for its permanent management; and also a statement as to the amount of endowment fund that will be necessary to provide for sufficient income for this purpose so that the financial support of the project will be assured. Carried.

Motion No. 17. That proposed budget of appropriations for 1917 be approved. Carried.

PROPOSED BUDGET OF APPROPRIATIONS FOR I9I7.

Appropriations for General Expenses:

\begin{tabular}{|c|c|c|}
\hline $\begin{array}{ll}\text { No. } & \text { I. } \\
\text { No. } & 2 .\end{array}$ & $\begin{array}{l}\text { Salaries. } \ldots \ldots \ldots \ldots \ldots \ldots \ldots \ldots \ldots \ldots \ldots \ldots \ldots \ldots \ldots \ldots \ldots \ldots \ldots \ldots \ldots \\
\text { Printing, Postage and Stationery } \ldots \ldots \ldots \ldots \ldots \ldots \ldots \ldots\end{array}$ & $\begin{array}{r}\$ 6,150.00 \\
1,000.00\end{array}$ \\
\hline No. 3 . & Clerical Expenses-Secretary's Office............ & $4 \mathrm{I} 6.00$ \\
\hline No. 4. & Miscellaneous Expenses.. & 200.00 \\
\hline fo. 5 . & Stenographers. & 350.00 \\
\hline fo. 6. & Traveling Exper & 200.00 \\
\hline 10. 7. & ee on Membership.. & 250.00 \\
\hline No. 8: & Committee on Unofficial Standards. . & 100.00 \\
\hline No. 9 . & Year Book. & $3, \infty 00.00$ \\
\hline No. Io. & Premium on Treas & 50.00 \\
\hline fo. I I. & National Drug Tr & 100.00 \\
\hline 1. 12. & on Scientific Pal & 25.00 \\
\hline o. 13. & on and Legislation $\ldots \ldots \ldots \ldots \ldots \ldots$ & 25.00 \\
\hline No. 14. & ts............... & 25.00 \\
\hline I5. & and Dispensing. . . . . . & 25.00 \\
\hline o. 16 & ical Pharmacy...... & 25.00 \\
\hline 7. & $\ldots \ldots \ldots \ldots$ & 25.00 \\
\hline 18. & Natio & 25.00 \\
\hline 19. & Committee on Recipe Book. & 50.00 \\
\hline
\end{tabular}

Appropriations for Open Accounts:

$\$ 12,041.00$

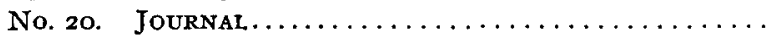

(a) Publication..................... $\$ 5,000.00$

(b) Clerical Expenses................. 800.00

(c) Postage and Stationery.............. 300.00

(d) Freight, Drayage and Miscellaneous......... I50.00

No. 21. National Formulary $\ldots \ldots \ldots \ldots \ldots \ldots \ldots \ldots \ldots \ldots \ldots$

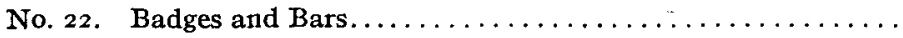

50.00

$7,350.00$ 
Motion No. 18 . Election of members Nos. 39 to 50 inclusive. Carried.

Motion No. 19. That the Chairman of the Council appoint a committee to prepare resolutions to be sent to the widow of the late Martin I. Wilbert, expressing the sympathies of the members of the Council to her, in her bereavement, and their appreciation of the valuable services Mr. Wilbert has rendered to American Pharmacy and the American Pharmaceutical Association. Carried. The committee named was S. L. Hilton, Dr. F. E. Stewart and H. V. Arny.

Motion No. 2o. Election of members Nos. 51 to 67 inclusive. Carried.

Motion No. 2r. Election of members Nos. 68 to 75 inclusive. Carried.

Motion No. 22. Election of members Nos. 76 to 102 inclusive. Carried.

Motion No. 23. That an additional \$roo be appropriated for the National Drug. Trade Conference. Carried.

Motion No. 24. Election of members Nos. 103 to 123 inclusive. Carried.

Motion No. 25. That the program for 1917 Annual Meeting as revised be approved. Carried.

Motion No. 26. That $\$ 2000$ be appropriated to the National Formulary IV account with which to pay bills for the National Formulary IV. Carried.

Motion No. 27. That Walter H. Cousins of Dallas, Texas, be elected to fill the vacancy of membership on the Commission of Proprietary Medicines caused by the death of the late Martin I. Wilbert. Carried.

Motion No. 28. That fifteen dollars be appropriated to the Committee on Patents and Trade Marks for expenses of committee. Carried.

Motion No. 29. Election of members Nos. 124 to 148 inclusive. Carried.

Motion No. 3o. That an additional appropriation of $\$ 100.00$ be made for National Drug Trade Conference. Carried.

Motion No. 31. Election of members Nos. 149 to 172 inclusive. Carried.

Motion No, 32. Election of members Nos. 173 to 227 inclusive. Carried.

Motion No. 33. That Samuel C. Henry, of Philadelphia, be elected to fill the vacancy in the Commission on Proprietary Medicines caused by the death of the late Thomas F. Main. Carried.

Motion. No. 34. That Caswell A. Mayo, of New York, be elected to fill the vacancy in the Committee on Transportation, as a member and chairman, caused by the death of the late Thomas F. Main. Carried.

Motion No. 35. Election of members Nos. 228 to 239 inclusive. Carried.

The report of the Committee on Publication was read and, on motion of F. E. Stewart, seconded by Otto F. Claus, was approved. It was as follows:

To the Members of the Council:

\section{GENTI,EMEN :}

The Committee on Publication submits the following report:

Reading Pages of the Journal.-The reading pages of the JoUrNaL for 1916 numbered 1422 , an average of 119 pages per month. In 1915 it was decided to reduce the number of reading pages to not more than $x 28$ per month. Last year the printing costs rose so greatly that we were compelled to reduce the reading pages of 1917 . For the first six months, these numbered, practically, 600 pages (592), or 1200 per year, or soo per month. This reduction, however, was more apparent than real, as it was accomplished by having authors condense their papers, with resultant advantage, both to the papers and the Association.

Expenditures for the Journal. - In our teport of last year it was estimated that, from the expenditures of the first seven months of 1916 , the expenditures for the year of 1916 for publication, etc., would be about $\$ 5600$, which, with the editor's salary $(\$ 3500)$, would equal $\$ 9100$. As a matter of fact, the actual cost of the I9I6 Journal (including the editor's salary) was $\$ 9123.07(\$ 5623.07+\$ 3500)$.

It was estimated, also, that the costs of getting out the JouRNAL in I 17 would be $\$ 5$ 50o more than in $I g I 6$, by reason of the enormously advanced costs of printing, etc. But we succeeded in placing a very advantageous contract for the printing and the increased costs were much less than anticipated. The expenditures for the first six months of 1917 (excluding the editor's salary) were only $\$ 3196.34$, or at the rate of about $\$ 6400$ for the year. 
Receipts of the Journal.-The receipts of the JournaL in I 916 from advertisements, etc., were $\$ 5478.21$.

In 1915 the receipts from advertisements, etc., were $\$ 3620.33$.

During the first six months of 1917 there have been received from advertisements, etc., $\$ 3$ I63.74. The indications, based on this record, are that the receipts for 1917 will be fully $\$ 6000$, an increase of about $\$ 500$ over 1916 , and about $\$ 2400$ over 1915 .

Net Cost of the Journal.--In I9I6 the total expenditures for the Journal (including salaries) were $\$ 9$ I 23.07, and the total receipts were $\$ 5478.21$, making a net cost of $\$ 3644.86$ for the year.

If the receipts of the JouRNAL for the twelve months of 1917 total $\$ 6000$ as we can reasonably hope, and the cost of getting it out does not exceed $\$ 6400$, as we expect, this means that the annual net cost of the JoURNaI for 1917 will exceed that of 1916 by only $\$ 400$, instead of $\$ 1500$, as we had expected, and also that the Journal, will be published at little cost to the Association except for editorial salary at a time when the costs of publication are fully 50 percent more than formerly.

The credit for this remarkable achievement is due to Editor Eberle who has labored most zealously, not only in minimizing expenditures and securing additional advertising-a difficult task at this time-but also in corresponding with authors and getting them to condense their papers, with the result of briefer and better papers, and with this, the high standing of the JourNaL. as the leading exponent of scientific pharmacy in this country has been maintained.

Condensation of Papers for the Journal.-In the matter of securing the condensation of papers for the Journal, Editor Eberle has acted with the approval of the Committee on Publication, but something more than this is needed, and the Committee on Publication endorses the suggestion of the New York Branch that the Council pass a rule that no article or report of more than ten pages (excepting the annual address of the President) shall be published by the Editor in the JoURnal, except by the unanimous consent of the members of the Committee on Publication, there being, in the rule, a qualifying clause that the absence of a vote within ten days from any member of the Committee on Publication shall be considered as assenting to the publication of the lengthy article.

Such a rule would obligate the authors to condense lengthy papers and would relieve the Editor and the Committee on Publication of embarrassment in their relations with the contributors to the JOURNAL.

Printing of Journal for I9I7.-The contract for printing the JouRNAL for 1917 was awarded to the Eschenbach Printing Company of Easton, Pa., on October 30, IgI6. As everyone knows, not only have the costs of all materials used in the making of journals enormously advanced, but the wages in the labor market of the printing world have greatly advanced, also. Hence, we were particularly fortunate in obtaining an exceedingly advantageous contract for printing the 1917 JoURnal, with the Eschenbach Printing Company, with the option of renewing the same contract for 1918 if exercised on or before October I, I9I7.

Year Book for 1915 ( Vol. 4). - The contract for printing the Year Book for 1915 was awarded to the Eischenbach Printing Company of Easton, Pa., on March I3, I91 7, "subject to contingencies beyond control such as strikes, accidents, embargoes, supply of raw materials, fires, goods, etc." Copy was furnished soon thereafter by Reporter Arny and the book was distributed on July 21 , Igr 7 .

As Reporter Arny graciously states: “The Report on the Progress of Pharmacy for the year I9I5 is the joint effort of the present reporter and his predecessor, Prof. Koch. Thanks to the latter gentleman and his diligent collaborators, the work of the present reporter has been largely the filling in of gaps and the task of final editing. At this time he desires to state that the credit for the valuable features of the Report is due largely to these gentlemen."

The reading pages of the 1915 Year Book totalled 600, those of the previous issue $860-$ a reduction of 260 pages. Nothing was lost by the condensation. The progress in pharmacy has been fully and completely reported, but tersely, with resultant benefit to the Association financially. For this the Association is under obligation to the able Reporter on the Progress of Pharmacy, Prof. H. V. Arny.

The IgI5 Year Book (Vol. 4) distributed last month, cost \$2901.94, including expressage, etc., which, with the salary of the Reporter on the Progress of Pharmacy (\$600) totalled $\$ 3501.94$. The cost of the previous volume was $\$ 2922.03$, which with the salary of the Reporter on the Progress of Pharmacy ( $\$ 600)$ amounted to $\$ 3522.03$. The cost for the 1914 and 1915 books is, therefore, practically identical, despite the increased printing costs of fully 50 percent. 
The Future of the Year Book.-At the Atlantic City meeting (Igr6) of the Association, the Committee on Publication discussed the future issuance of the Year Book and recommended that a statement of the facts of the case be mailed to the membership in November (1916) with the official ballot and each member be requested to express his or her views on the subject. The recommendation was agreed to and the ballots distributed. Seven queries on the continuance or discontinuance of the Year Book under stated conditions were given and the results published in the Journal (rgr 7 , February number, p. 184 ).

The results clearly indicated that the membership wished the Year Book continued as heretofore, with no increase in membership dues; and as this is the expressed wish of the Association by ballot, the decision is final.

Fortunately, the treasury of the Association is, today, in a better financial condition than it has ever been before, and unless the existing war conditions make printing costs prohibitory, there is, apparently, no reason why the expressed wish of the membership cannot be complied with.

Issuance of Year Book of 1916 (Vol. 5).-Reporter Arny writes: "Work on the mss. of the 1916 Year Book (Vol. 5) is progressing nicely. I find that there are about the same number of papers as last year (about $\mathrm{I} 200$ ), and of these only about 200 remain to be made before the mss. of rgr6 Year Book will be ready for the final editing. Most of these abstracts are in the hands of my collaborators and will most likely be in my hands at the time of the Indianapolis meeting.

The 1916 Year Book should be issued late in 1917 or early in 1918 . The criticism is sometimes made that these books are not gotten out earlier, but few members have any conception of the labor involved in the condensation of 1200 or more papers, and also the fact that conditions are different now than when the fiscal year of the Association ended on July $\mathrm{r}$, and not on December 31 , as at present.

With the exception of the 1911 Proceedings, which covered a period of eighteen months (July I, 1910, to December 3I, I9I I), all the Proceedings have been for periods of the former fiscal year, $i$. e., from July I to July $I$. Thus, the 19 ro Proceedings was from July 1 , I gog, to June 30 , 1910 ; 1909, from July I, I908, to June 30, I909; 1908, from July I, 1907, to June 30, 1908, etc. In other words, with the Proceedings it usually took a year's time before the Proceedings for the year was gotten out, and not a few months only, as the "year-number" of the volumes might imply.

The Year Book is now issued, of course, for the fiscal year of the Association, i. e., January I to December $3 \mathrm{~T}$.

Sales of National Formulary, Fourth Edition.-23,000 copies of N. F. IV have been printed and bound. Of these the stock remaining on hand on June I, I9I7, was 2873 ( 1773 Muslin, 963 Buckram and 137 Interleaved). In other words, practically 20,000 have been sold since the first copy was issued on July 25, 1916. The General Secretary will present in his annual report a statement as to the distribution of the book and the Treasurer in bis report a statement as to the receipts and expenditures.

The Committee on Publication wishes especially to emphasize the fact that the "net receipts" for the book as given in the Treasurer's report are not the "net profits"-that, in order to fairly determine the latter, there should be charged against the receipts the "overhead expenses" since the issuance of the previous edition of the book in 1916 , including a proper proportion of the cost of salaries of officials and the cost of the research work utilized by the Committee on National Formulary in its work, such as the Proceedings, the Year Book and the Journal-all of which embrace research work, and all of which contribute, directly and indirectly, to the National Formulary. If this is done, then the "net receipts" will be so reduced that the "net profits" will be seen to be small, if not negligible.

Copyright of N.F.IV.-Application for copyright of the National Formulary, Fourth Edition, was made to Thorwald Solberg, Register of Copyrights, Washington, D. C., in the name of the American Pharmaceutical Association and was granted. The date of publication was August 15, 19I6; the affidavit was received November 20, 1916; the copies of the two books required to be deposited in the Library of Congress were received November 20, 1916, and the entry was Class A, XXc, No. 446,505.

Permission for Use of Portions of Text of U.S.P.IX in N. F.IV.-Application was made to the Board of Trustees of the U. S. P. C. to use certain portions of text of U.S. P. IX in N. F. IV, which was granted, a nominal charge of twenty-five dollars being made for such use. 
Permission Granted for Partial Use of Text of N.F.IV.- Since our last report the following applications for the partial use of the N. F. IV have been made and granted:

(I) "Treatise of Pharmacy." By Charles Caspari, Jr. By Lea and Febiger.

(2) "Publications of N. A. R. D. for Propagandic Work." National Association of Retail Druggists. Otto E. Bruder, Propagandic Director.

(3) "Materia Medica." By David M. R. Culbreth, M.D. Published by Lea and Febiger.

(4) "Key to the U. S. P. and N. F." By D. O. Haynes and Company.

(5) "The Physicians Drug Codex." By the Medical Council.

(6) "U. S. Dispensatory," Twentieth Edition. By the J. B. Lippincott Company. (Part I.)

(7) "Gray's Pharmaceutical Quiz Compend." By Mrs. M. M. Gray.

(8) "Sayre's Organic Materia Medica." By P. Blakiston's Son and Company.

(9) "Wright's Guide to the Organic Drugs of the Pharmacopoeia and National Formulary." By Eli Lilly and Company.

(ro) "Buckley's Dental Materia Medica." By P. Blakiston's Sons and Company.

(II) "U. S. Dispensatory," Twentieth Edition. By the J. B. Lippincott Company (partial use of text of descriptions of crude drugs in Part II of N. F. IV).

Changes in the Pharmacopoeia and the National Formulary.-It is interesting to state that the Hygienic Laboratory, U. S. Public Health Service, Treasury Department, has compiled and has recently issued "Bulletin No. I07" (July, I9I7) giving "A Digest of the Changes and Requirements Included in the Pharmacopoeia of the United States (Ninth Decennial Revision) and in The National Formulary (Fourth Edition) with References to the Titles Not Continued from the Preceding Editions."

Such a digest will be of much practical value to physicians and pharmacists in enabling them to readily ascertain the changes made in the official standards.

Complimentary Copies of N. F.IV, Series B, to Members of Committee on National Formulary. -At the suggestion of Otto Raubenheimer, each member of the Committee on National Formulary was sent a copy of Series B of N. F. IV, so that he could check up the corrections of text and also have on hand for reference a copy of the N. F. IV that was entirely free from mistakes.

A copy of the N. F. IV was sent to the Chairman of the Board of Trustees of the U. S. P. C., for inspection as to use of parts of text of U. S. P. IX in N. F. IV.

Hygienic Laboratory, U. S. Public Health Service (2 copies furnished).

Selling N. F. IV in Foreign Countries. - The sale of the N. F. IV in foreign countries is, of course, impracticable under existing war conditions, and possibly under normal conditions. There is no profit in the business for foreign dealers at present prices. The postal rates to most. foreign countries is the same as our eighth zone, 12 cents per pound or fraction thereof. If foreign business is desired, it should be arranged for the foreign dealers to sell above the retail prices in this country, but we do not think it necessary to consider the subject at this time. We hold the same opinion with reference to the publication of the N. F. IV in Spanish, which has been suggested.

J. W. England, Chairman.

The report of the editor was read and on motion of $\mathrm{H}$. C. Fuller, seconded by J. L. Turner, it was approved. It was as follows:

To the Council of the American Pharmaceutical Association:

Philadelphia, August I, 1917.

\section{DEAR SIRS:}

I herewith respectfully submit my report as Editor and Advertising Manager of the JourNAL of the American Pharmaceutical Association. In order that you may have figures for comparison: the total receipts of the JouRNAL, for 1914 were $\$ 3539.39$; for $1915, \$ 3620.33$.

The reports submitted show in detail the receipts and expenses for the year 1916, and separately for the seven months up to August I, of I9I 7 . The expenses do not include the Editor's salary. It should perhaps be stated that vouchers for all expenses go to the General Secretary, and all expenses are thereupon paid by the Treasurer. All checks received are made payable to the Treasurer. A monthly statement is made to the Publication Committee of all transactions, and also a summary at the end of every quarter.

It will be seen that the total income for 1916 was $\$ 5478.21$, exceeding that of 1914 by $\$ 1938.82$, 
and that of 1915 by $\$ 1857.88$. The expenses for 1916 were $\$ 5623.07$; thus, the expenses exceeded the receipts by $\$ 144.86$. I have not an account of the expenses of preceding years, but for the last six months of 1915 they were $\$ 2999.27$, while for the corresponding months of 1916 they were $\$ 2773.40$, showing that for the corresponding months the expenses were $\$ 225.87$ less in 1916 than in 1915. This was largely due to a more favorable publication contract.

The total expense is divided as follows: $\$ 4431.13$ for publication of the Jotrnal; $\$ 243.45$ for mailing; express and freight, $\$ 50.81$; binding, reprints and stencils, $\$ 44.27$; engravings and etchings, $\$ 88.36$; commissions on advertising, $\$ 70.62$; clerical expense $\$ 532.75$; office postage, \$1 7.18; stationery and office supplies, $\$ 44.50$.

Of the receipts, $\$ 5225.57$ came from advertising, $\$ 244.64$ from subscriptions, sale of single copies and bound volumes, and $\$ 8.00$ from reprints. With the exception of two sets of reprints, $\mathrm{J}$. B. Lippincott Co. handled that business as the Association was making no profit out of it, since the printing of them is for the convenience of the contributors.

Our 1916 contract was made only for one year, and prices of paper and other printing material having advanced beyond reasonable expectations, it was necessary to make a new contract which foreboded an increase of cost of nearly 50 percent. The demand for chemicals and shortage of material made the securing of new advertising more than difficult. Fortunately, we can report conditions for 1917 , up to August $I$, that are exceedingly encouraging.

The receipts up to August $I, 1917$, are $\$ 3684.05$, while the total expenses for the same months are $\$ 3663.99$. For comparison with the same months of 1916 , we have receipts $\$ 3437.11$ and expenses $\$ 3257.38$. Thus while our expenses for the seven months have increased, our receipts have also, so that by August $\mathrm{I}$, the difference between receipts and expenses of the seven months amounts to only $\$ 159.67$ more up to August I than for the same period of last year. I am sure this is gratifying to those who were feariul of a decidediy increased difference, for the figures indicate a relation between receipts and expenses as favorable as last year, when the cost of producing the JoLrNAL was lower.

The increased cost is due almost entirely to the higher cost of producing the JournaL, and the increased office postage is due to the fact that of necessity there is much mailing and remailing of copy, proof, etc., to Publication Office. Our receipts for 1917 are still slightly in excess of the cost of production, tramely, by $\$ 20.06$.

In I915, we had 26 non-member subscribers to the JorRNAL, at present, we have 47 , and while numerically this is small, as the advantages received by joining the Association in paying an additional dollar are quickly recognized, however, it shows that there is some outside increasing interest in the publication. In writing to prospective subscribers, we invariably call attention to the advantage of membership, whereby they also receive the Year Book.

Aside from such assistance, it must also be remembered that the JoLRNAl, prepares the way for the publication of the A. Ph. A. Recipe Book. In one sense this might be considered an expense to the Jourxar, that the Association should provide for in another account. But this is what the Journal is for: to be of greatest value to pharmacy and the Association. In this connection the Editor desires to express appreciation of the work of Prof. Otto Raubenheimer and the Committee on the A. Ph. A. Recipe Book. It should be a means of bringing more members into the Association.

The JournaI. is an integral in the Research Work of the American Pharmaceutical Association, which is part of the contributory service to other related professions and activities, coördinating the benefits thereof for the general good of humanity, and which entitles pharmacy to recognition as a profession. The JOURNAL is an essential link in this chain of coopperation as well as in the upbuilding of the Association; as necessary to American pharmacy as like mediums are to medicine, to chemistry, every other profession, the arts and the industries.

The Editor consults freely with the Publication Committee, and sometimes thinks that he tries the patience of the members, but they have been considerate, and he desires to thank them for their helpfulness. The Fiditor endeavors to serve the members of the Association to the best of his ability and judgment and expresses thanks to the contributors and all members for their uniform kindness and consideration, and welcomes the advice that will make the JocRNAL better and more serviceable.

The largest source of income for the JoURNaL is derived from advertising patrons. They realize the value of the JournaL for delivering their messages to pharmacists. There are, however, 
many others who could be induced to use the advertising pages if the members would encourage them to do so. Also, if members would occasionally refer, in writing to advertisers, to the fact that they had noticed the advertisements, it would be helpful. The Editor would like to see the time come when the Journal can be produced without any cost whatever to the Association; this is not impossible, if the members will help in the manner indicated.

In conclusion the Editor hopes that his efforts and the results of his work may meet the approval of the membership whom he strives to serve to the best of his ability.

Thanking you,

Sincerely,

E. G. EBARLE.

Adjourned to meet Wednesday, August 29, 1917, at 7.00 P.M.

J. W. ENGLAND,

Secretary.

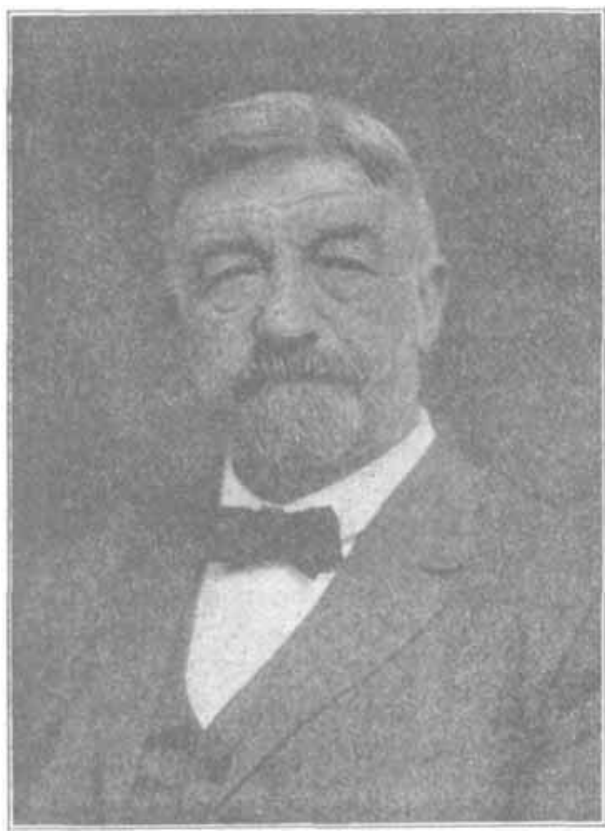

CHARLES HOLZHAUER, Newark, N. J. President of American Pharmaceutical Association

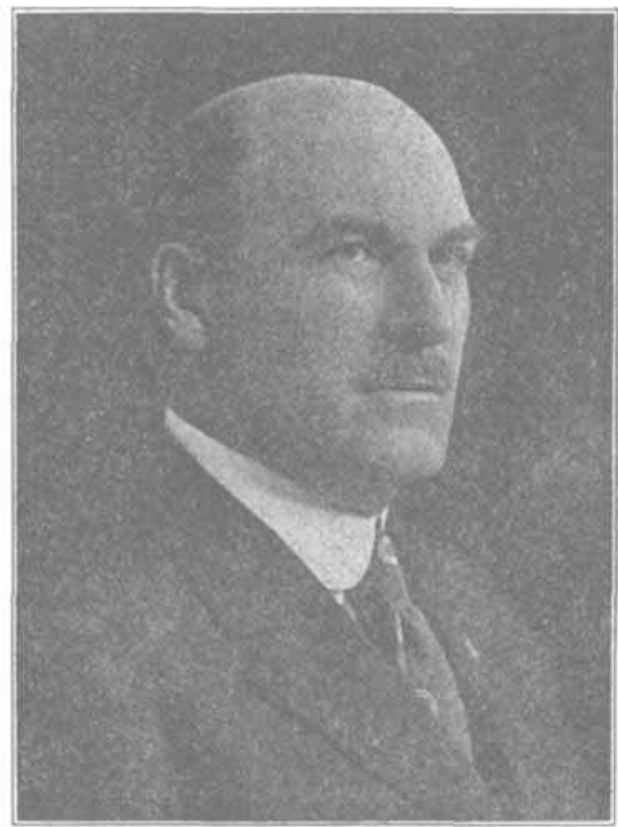

H. C. CHRISTENSEN, Chicago

Secretary National Association of Boards of Pharmacy 